J. Amer. Soc. Hort. Sci. 118(2):201-206. 1993.

\title{
Application of Calcium to Soil and Cultivar Affect Elemental Concentration of Watermelon Leaf and Rind Tissue
}

\author{
W. Dennis Scott', B. Dean McCraw', James E. Motes², and Michael W. Smith ${ }^{2}$ \\ Department of Horticulture and Landscape Architecture, Oklahoma State University, Stillwater, \\ OK 74078-0481
}

Additional index words. Citrullus lanatus, blossom-end rot, calcium, gypsum

\begin{abstract}
Field experiments were conducted to quantify the effect of Ca supplied as gypsum in factorial combination with watermelon [Citrullus launatus (Thumb) Matsum and Nakai] cultivars Charleston Gray, Crimson Sweet, and Tri-X Seedless on yield and the elemental concentration of leaf and rind tissue. Also, the effect that ontogenetic changes and sectional differences had on the elemental concentration in rind tissue was investigated. The experiments were conducted at two locations in Oklahoma. Yield was not affected by Ca; however, mean melon weight was reduced at $1120 \mathrm{~kg} \mathrm{Ca/ha}$. Leaf Ca concentration increased linearly in response to $\mathrm{Ca}$ rate. 'Tri-X Seedless' had lower leaf $\mathrm{Ca}$ and higher $\mathrm{K}$ concentrations than did 'Charleston Gray' or 'Crimson Sweet'. Fruit ontogeny (days from anthesis) and melon section (blossom or stem-end) interacted to affect elemental concentrations in the rind tissue. There was also a significant genotypic effect on elemental concentration in rind tissue. Increasing rates of $\mathrm{Ca}$ applied to soil reduced the incidence of-blossom-end rot (BER) in 'Charleston Gray' melons. Calcium treatment did not affect flesh redness or soluble solids concentration (SSC) of watermelon.
\end{abstract}

Adequate Ca nutrition is essential for normal plant growth and development (Kirkby and Pilbean, 1984). Soil water status, root vigor, relative humidity, wind, high substrate soluble salt concentration, and cultivar selection can affect Ca nutrition (Wiersum, 1979). Several Ca deficiency disorders have been described, including BER of pepper (Capsicum annuum L.), tomato (Lycopersicon esculentum Mill.), and watermelon (Shear, 1975). These disorders are related more to inefficient partitioning of $\mathrm{Ca}$ within the plant than to limited uptake (Bangerth, 1979). Low transpiring organs, such as fruits and enclosed tissue, accumulate less $\mathrm{Ca}$ than leaves from the same plant (Bangerth 1976).

In field trials, watermelon cultivars with cylindrical or subcylindrical fruit generally are highly susceptible to BER, while spherical-fruited cultivars are completely or highly resistant (Cirulli, 1974; Cirulli and Ciccarese, 1981).

Studies of the effects of lime on watermelon yield have been conducted with variable results (Bradley and Fleming, 1959; Jones et al., 1975; Lacascio and Lundy, 1962). Increasing rates of Ca, supplied as gypsum $\left(\mathrm{CaSO}_{4}\right)$, were shown to reduce watermelon yield (Sundstrom and Carter, 1983). Watermelons grown in sand culture provided progressively more $\mathrm{Ca}$, supplied as $\mathrm{CaCl}_{2}$, and showed increased concentrations of $\mathrm{Ca}$ in leaf and fruit tissue (Walters and Nettles, 1961). Data were not available for Ca accumulation in watermelon fruit grown in field plots or respondent $\mathrm{Ca}$ status in developing watermelon rind tissue.

Objectives of this study were to 1) determine if the rate of $\mathrm{Ca}$ applied to soil affects the accumulation of Cain leaf and rind tissue,

Received for publication 7 Oct. 1991. Accepted for publication 12 Sept. 1992. J. Article no. J-6044 of the Agr. Expt. Sta., Oklahoma State Univ., Stillwater. The information given in this publication is for educational purposes only. Mention of a trademark, proprietary product, or vendor does not constitute a guarantee or warranty of the product nor does it imply approval or disapproval to the exclusion of other products or vendors that may also be suitable. The cost of publishing this paper was defrayed in part by the payment of page charges. Under postal regulations, this paper therefore must be hereby marked advertisement solely to indicate this fact.

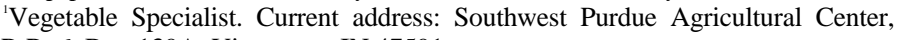
R.R. 6, Box 139A, Vincennes, IN 47591.

${ }^{2}$ Professor.
2) determine the influence of growth stage on watermelon fruit $\mathrm{Ca}$ concentration, 3) evaluate phenotypic response of selected watermelon cultivars to increasing soil Ca content, and 4) determine if $\mathrm{Ca}$ application rate affects the incidence of BER.

\section{Materials and Methods}

The field experiments were conducted at the Vegetable Research Station, Bixby, Okla., on a Sevem fine sandy loam [coarsesilty, mixed (calcareous), thermic Typic Udifluvents] and at the Research Nursery and Teaching Arboretum, Stillwater, Okla., on a Norge loam [fine-silty, mixed, thermic Udic Paleustolls] during the growing seasons of 1989 and 1990. Nitrogen was preplantincorporated to supply $34 \mathrm{~kg} \cdot \mathrm{ha}^{-1}$ at both locations, and plants were sidedressed to supply $34 \mathrm{~kg} \mathrm{~N} / \mathrm{ha}$ at 4 weeks after transplanting. The top $20 \mathrm{~cm}$ of soil had a water $\mathrm{pH}$ ranging from 6.1 to 6.4 at Bixby and 5.5 to 5.9 at Stillwater. Soil tests showed that native levels of $\mathrm{P}$ and $\mathrm{K}$ were adequate. Black polyethylene mulch $(1.2 \mathrm{~m}$ wide $\times 0.08 \mathrm{~mm}$ thick) and trickle irrigation hose (Bi-wall, Hardie Irrigation, Luguna Niguel, Calif.) with $0.38 \mathrm{~mm}$ diameter holes 30 $\mathrm{cm}$ apart were mechanically laid in rows on $5 \mathrm{~m}$ centers.

Three-week-old transplants grown in $100 \mathrm{~cm}^{3}$ peat pots containing commercial peat-lite mix were in the three leaf stage when planted five per plot, $1.2 \mathrm{~m}$ apart. Transplanting was accomplished on 6 and 9 May 1989 and 19 and 23 May 1990 at Bixby and Stillwater, respectively. Soil water potential was maintained between 20 to $30 \mathrm{kPa}$ with the aid of tensiometers installed $30 \mathrm{~cm}$ deep (Bhella, 1985).

2,6-dinitro-N,N-dipropyln-4-(trifluoromethyl) benzenamine (trifluralin) at $840 \mathrm{~g} \cdot \mathrm{ha}^{-1}$ was incorporated between rows at the time of transplanting. Accepted commercial foliar insecticides were used including methyl-N-[(methylamino) carbonyl] oxylethanimidothioate (methomyl) and (S)-cyano(3-phenoxyphenyl)methyl-(S)-4-chloroalpha-(1-methyethyl) benzeneacetate (fenvalerate).

A`bbreviations: BER, blossom-end rot; SSC, soluble solids concentration. 
Table 1. Influence of soil applied gypsum $\left(\mathrm{CaSO}_{4}\right)$ on the yield of watermelon. ${ }^{2}$

\begin{tabular}{|c|c|c|}
\hline & Bixby & Stillwater \\
\hline $\begin{array}{l}\text { Ca rate } \\
\left(\mathrm{kg} \cdot \mathrm{ha}^{-1}\right)\end{array}$ & $\begin{array}{c}\text { Melon wt } \\
(\mathrm{kg})\end{array}$ & $\begin{array}{l}\text { Melon wt } \\
(\mathrm{kg})\end{array}$ \\
\hline 0 & 9.06 & 10.17 \\
\hline 280 & 9.18 & 10.00 \\
\hline 560 & 9.56 & 10.22 \\
\hline 1120 & 9.22 & 10.14 \\
\hline Linear & NS & NS \\
\hline Quadratic & $*$ & NS \\
\hline
\end{tabular}

${ }^{\overline{ }}$ Means of 2 years, three cultivars.

, $*$ Nonsignificant or significant at $P=0.05$.

Gypsum treatments in factorial combination with three cultivars were incorporated into a $1.5 \mathrm{~m}$ wide band and $18 \mathrm{~cm}$ deep at $0,280,560$, and $1120 \mathrm{~kg} \cdot \mathrm{ha}^{-1} \mathrm{Ca} 1$ week before transplanting. The cultivars, chosen to provide a range in susceptibility to BER, were 'Charleston Gray' (highly susceptible), 'Crimson Sweet' (intermediate), and 'Tri-X Seedless' (resistant). The experimental design was a split-split-split-plot, with three replications in 1989 and four in 1990. Gypsum was the main-plot, cultivar the subplot, the stage of development the sub-sub-plot, and the watermelon rind section the sub-sub-sub-plot.

Flowers were tagged at anthesis in both years. One fruit per plot was then sampled for elemental analyses at 14 and 21 days after anthesis and at maturity in 1989 and at 10 and 20 days after anthesis and at maturity in 1990. Fruit maturity among and between cultivars varied from 30 to 35 days after anthesis. Fruit samples ( $300 \mathrm{~g}$ fresh weight) were taken from the blossom and stem end of fourteen 21 day old and mature fruit. Leaf samples consisting of the first fully expanded leaf (lamina and petiole) were taken at anthesis in both years.

Fruit and leaf samples were dried at $80 \mathrm{C}$ for 7 days, ground to pass a mesh screen with $0.16 \mathrm{~cm}^{2}$ openings, and stored in air-tight jars. Before analysis, samples were redried at $80 \mathrm{C}$ for $24 \mathrm{~h}$. Total Ca was determined using the dry ash method (Isaac and Johnson, 1975), and extractable Ca was determined using a $2 \%$ acetic acid extraction (Gallaher and Jones, 1976). Standard methods were used for analysis of $\mathrm{K}, \mathrm{Mg}, \mathrm{Zn}, \mathrm{Fe}$, and $\mathrm{Mn}$ by atomic absorption spectroscopy (Perkin-Elmer, Model 303, Norwalk Corm.).

Watermelon fruits of marketable maturity were harvested four times at 1 -week intervals beginning 31 July in 1989 and 6 Aug. in 1990. The number of fruits, their respective weights, and number of BER-affected fruits were determined. A single mature watermelon from each plot was sampled for SSC and redness. Color was determined by scanning the placental tissue with a Minolta CR200 chroma meter (Minolta, Ramsey, N.J.). Values of Hunter's L, $\mathrm{a}$, and b were taken. Only the ' $\mathrm{a}$ ' value data (redness) are presented
(Francis, 1980). Homogenate from test watermelons was filtered through Whatman no. 6 filter paper, and SSC was measured on a Fisher Scientific Co. Refractometer, Model no. ABBE-3L (Dallas) equipped with circulating water temperature control set at $20 \mathrm{c}$.

\section{Results}

There were no interactions between $\mathrm{Ca}$ or cultivar with years; therefore, data are pooled for years. Calcium had no significant effect on watermelon yield ( 31 to $37 \mathrm{Mt} \cdot \mathrm{ha}^{-1}$ at Bixby, 38 to 41 $\mathrm{Mta} \mathrm{ha}^{-1}$ at Stillwater). This result contrasts with those of previous reports (Sundstrom and Carter, 1983; Walters and Nettles, 1961). In treatments where $\mathrm{Ca}$ was supplied at $1120 \mathrm{~kg} \cdot \mathrm{ha}^{-1}$, mean melon

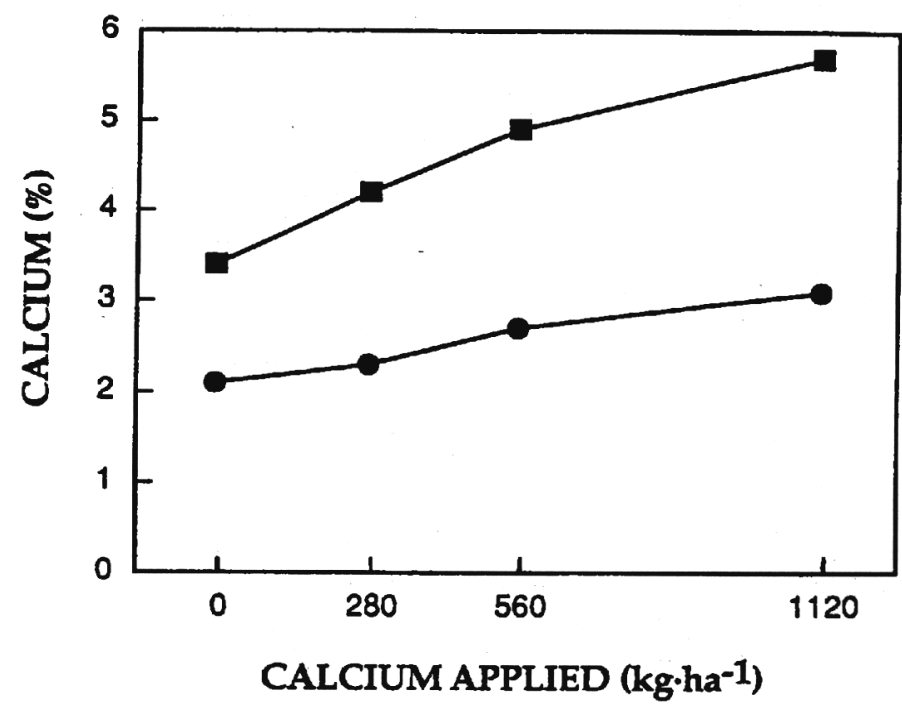

Fig. 1. Effect of soil applied $\mathrm{Ca}\left(\mathrm{CaSO}_{4}\right)$ on the concentration of total and extractable Cain watermelon leaf tissue. Total $\mathrm{Ca}(\boldsymbol{\square})$ and extractable $\mathrm{Ca}(\boldsymbol{\bullet})$ values are means of two locations, three cultivars, and four replications (1990).

weight at Bixby but not at Stillwater decreased when compared to melons grown at the $560 \mathrm{~kg} \cdot \mathrm{ha}^{-1}$ and lower rates (Table 1). All three cultivars yielded similarly (data not shown); however, mean melon weights, as yield, were higher in melons cultured at Stillwater than at Bixby. Soil $\mathrm{pH}$ values within $\mathrm{Ca}$ treatments were not influenced by gypsum rate.

Concentrations of total and acetic acid extractable $\mathrm{Ca}$ in watermelon leaf tissue were positively related to soil incorporated $\mathrm{Ca}$ (Fig. 1). When no Ca was applied, $61 \%$ of the total Ca fraction $\left(2.11 \mathrm{pg} \cdot \mathrm{g}^{-1}\right)$ was extractable with $2 \%$ acetic acid solution. The extractable $\mathrm{Ca}$ fraction remained relatively constant at all $\mathrm{Ca}$ rates, ranging from $55 \%$ to $61 \%$ of the total $\mathrm{Ca}$ in the leaf tissue. The

Table 2. Effect of cultivar on watermelon leaf elemental concentration.

\begin{tabular}{|c|c|c|c|c|c|c|c|}
\hline \multirow[b]{4}{*}{ Cultivar } & \multicolumn{7}{|c|}{ Elemental concn } \\
\hline & \multicolumn{4}{|c|}{ Dry wt (\%) } & & & \\
\hline & Total & Ext. & & & \multicolumn{3}{|c|}{ Dry wt $\left(\mu g \cdot g^{-1}\right)$} \\
\hline & $\mathrm{Ca}$ & $\mathrm{Ca}^{y}$ & $\mathrm{~K}$ & $\mathrm{Mg}$ & $\mathrm{Zn}$ & $\mathrm{Fe}$ & $\mathrm{Mn}$ \\
\hline Charlston Gray & $4.69 \mathrm{a}$ & $2.72 \mathrm{a}$ & $1.68 \mathrm{~b}$ & $0.59 \mathrm{~b}$ & $30 \mathrm{ab}$ & $111 \mathrm{~b}$ & $138 \mathrm{~b}$ \\
\hline Crimson Sweet & $5.01 \mathrm{a}$ & $2.91 \mathrm{a}$ & $0.62 \mathrm{~b}$ & $0.70 \mathrm{a}$ & $34 \mathrm{a}$ & $126 \mathrm{a}$ & $182 \mathrm{a}$ \\
\hline Tri-X-Seedless & $4.13 \mathrm{~b}$ & $2.40 \mathrm{~b}$ & $2.01 \mathrm{a}$ & $0.51 \mathrm{~b}$ & $29 \mathrm{~b}$ & $113 \mathrm{~b}$ & $122 \mathrm{~b}$ \\
\hline
\end{tabular}

${ }^{\overline{ }}$ Means of 2 years, two locations, and four Ca treatments. Mean separation in columns by Duncan's multiple range test, $P=0.05$. 
acetic acid extraction results in a concentration representative of all plant $\mathrm{Ca}$, except that crystallized as $\mathrm{Ca}$ oxalate (Gallaher and Jones, 1976).
Genotype significantly influenced the elemental concentration of watermelon leaf tissue (Table 2). 'Charleston Gray' and 'Crimson Sweet' had similar concentrations of total and extractable $\mathrm{Ca}$,

Table 3. Influence of $\mathrm{Ca}$ rate and rind section on the concentration of total and extractable $\mathrm{Ca}$ in watermelon rind tissue.

\begin{tabular}{|c|c|c|c|c|c|c|c|c|c|}
\hline \multirow[b]{4}{*}{$\begin{array}{l}\text { Ca rate } \\
\left(\mathrm{kg} \cdot \mathrm{ha}^{-1}\right)\end{array}$} & \multirow[b]{4}{*}{$\begin{array}{l}\text { Rind } \\
\text { section }^{y}\end{array}$} & \multicolumn{8}{|c|}{ Ca concn (\% dry wt) } \\
\hline & & \multicolumn{4}{|c|}{ Bixby } & \multicolumn{4}{|c|}{ Stillwater } \\
\hline & & \multicolumn{2}{|c|}{1989} & \multicolumn{2}{|c|}{1990} & \multicolumn{2}{|c|}{1989} & \multicolumn{2}{|c|}{1990} \\
\hline & & $\begin{array}{c}\text { Total } \\
\mathrm{Ca}\end{array}$ & $\begin{array}{l}\text { Ext. } \\
\mathrm{Ca}^{\mathrm{x}}\end{array}$ & $\begin{array}{c}\text { Total } \\
\mathrm{Ca}\end{array}$ & $\begin{array}{l}\text { Ext. } \\
\mathrm{Ca}\end{array}$ & $\begin{array}{c}\text { Total } \\
\mathrm{Ca}\end{array}$ & $\begin{array}{c}\text { Ext. } \\
\mathrm{Ca}\end{array}$ & $\begin{array}{c}\text { Total } \\
\text { Ca }\end{array}$ & $\begin{array}{c}\text { Ext. } \\
\mathrm{Ca}\end{array}$ \\
\hline \multirow[t]{4}{*}{0} & $\mathrm{BE}$ & 0.85 & 0.35 & 0.52 & 0.30 & 0.78 & 0.35 & 0.51 & 0.28 \\
\hline & MT & 0.98 & 0.42 & 0.48 & 0.30 & 0.60 & 0.25 & 0.44 & 0.31 \\
\hline & MB & 1.08 & 0.47 & 0.61 & 0.25 & 0.74 & 0.27 & 0.51 & 0.23 \\
\hline & $\mathrm{SE}$ & 1.01 & 0.37 & 0.61 & 0.29 & 0.82 & 0.42 & 0.62 & 0.27 \\
\hline \multirow[t]{4}{*}{280} & $\mathrm{BE}$ & 0.76 & 0.31 & 0.51 & 0.29 & 0.81 & 0.39 & 0.54 & 0.28 \\
\hline & MT & 0.90 & 0.35 & 0.47 & 0.26 & 0.67 & 0.28 & 0.52 & 0.41 \\
\hline & MB & 1.05 & 0.45 & 0.58 & 0.22 & 0.79 & 0.29 & 0.69 & 0.27 \\
\hline & SE & 0.92 & 0.34 & 0.65 & 0.30 & 0.98 & 0.52 & 0.65 & 0.29 \\
\hline \multirow[t]{4}{*}{560} & $\mathrm{BE}$ & 0.70 & 0.27 & 0.55 & 0.30 & 0.85 & 0.42 & 0.55 & 0.32 \\
\hline & MT & 1.01 & 0.34 & 0.43 & 0.29 & 0.66 & 0.27 & 0.47 & 0.37 \\
\hline & MB & 0.93 & 0.44 & 0.60 & 0.21 & 0.74 & 0.28 & 0.57 & 0.24 \\
\hline & $\mathrm{SE}$ & 0.85 & 0.26 & 0.63 & 0.32 & 0.91 & 0.59 & 0.64 & 0.31 \\
\hline \multirow[t]{4}{*}{1120} & BE & 0.84 & 0.34 & 0.53 & 0.30 & 0.80 & 0.39 & 0.52 & 0.29 \\
\hline & MT & 0.97 & 0.43 & 0.47 & 0.30 & 0.81 & 0.35 & 0.49 & 0.35 \\
\hline & MB & 1.30 & 0.63 & 0.62 & 0.23 & 0.84 & 0.30 & 0.62 & 0.23 \\
\hline & $\mathrm{SE}$ & 1.00 & 0.36 & 0.67 & 0.32 & 0.83 & 0.57 & 0.63 & 0.28 \\
\hline \multicolumn{10}{|c|}{ LSD 0.05} \\
\hline \multicolumn{2}{|c|}{$\begin{array}{l}\text { Section within Ca rate } \\
\text { Ca rate within section }\end{array}$} & 0.12 & 0.1 & 0.11 & 0.04 & 0.06 & 0.06 & 0.09 & 0.03 \\
\hline \multicolumn{2}{|c|}{ Linear } & NS & NS & NS & NS & NS & NS & NS & NS \\
\hline \multicolumn{2}{|c|}{ Quadratic } & NS & $*$ & NS & NS & $*$ & $*$ & $*$ & $*$ \\
\hline
\end{tabular}

${ }^{2}$ Values mean of three cultivars and four Ca rates.

'BE = blossom-end, $\mathrm{MT}=$ middle top, $\mathrm{MB}=$ middle bottom, $\mathrm{SE}=$ stem-end.

Ns, $*$ Nonsigniticant or significant at $P=0.05$.

${ }^{\times}$Acetic acid extractable Ca.

Table 4. Influence of sampling time and section on the elemental concentration of watermelon rind (1989).

\begin{tabular}{|c|c|c|c|c|c|c|c|c|c|c|c|c|c|c|c|}
\hline \multirow{5}{*}{$\begin{array}{l}\text { Sample } \\
\text { time }\end{array}$} & \multirow{5}{*}{$\begin{array}{c}\text { Rind } \\
\text { section }^{\mathrm{y}}\end{array}$} & \multicolumn{14}{|c|}{ Elemental concn } \\
\hline & & \multicolumn{7}{|c|}{ Bixby } & \multicolumn{7}{|c|}{ Stillwater } \\
\hline & & \multicolumn{4}{|c|}{ Dry wt (\%) } & & & & \multicolumn{4}{|c|}{ Dry wt (\%) } & & & \\
\hline & & Total & Ext. & & & & $v t(\mu$ & & Total & Ext. & & & \multicolumn{3}{|c|}{ Dry wt $\left(\mu \mathrm{g} \cdot \mathrm{g}^{-1}\right)$} \\
\hline & & $\mathrm{Ca}$ & $\mathrm{Ca}^{\mathrm{x}}$ & $\mathbf{K}$ & $\mathrm{Mg}$ & $\mathrm{Zn}$ & $\mathrm{Fe}$ & $\mathrm{Mn}$ & $\mathrm{Ca}$ & $\mathrm{Ca}$ & $\mathrm{K}$ & $\mathrm{Mg}$ & $\mathrm{Zn}$ & $\mathrm{Fe}$ & $\mathrm{Mn}$ \\
\hline \multirow[t]{2}{*}{14 days $^{w}$} & $\mathrm{BE}$ & 0.68 & 0.38 & 4.33 & 0.32 & 30 & 52 & 13 & 0.75 & 0.37 & 4.76 & 0.49 & 48 & 55 & 11 \\
\hline & SE & 0.88 & 0.34 & 5.98 & 0.43 & 49 & 66 & 16 & 0.97 & 0.55 & 5.60 & 0.42 & 39 & 65 & 30 \\
\hline \multirow[t]{2}{*}{21 days } & $\mathrm{BE}$ & 0.87 & 0.27 & 6.47 & 0.38 & 37 & 63 & 20 & 0.75 & 0.35 & 6.42 & 0.42 & 42 & 43 & 12 \\
\hline & SE & 0.90 & 0.28 & 6.79 & 0.38 & 42 & 58 & 26 & 0.93 & 0.42 & 5.70 & 0.40 & 43 & 53 & 28 \\
\hline \multirow[t]{2}{*}{ Maturity } & $\mathrm{BE}$ & 0.81 & 0.27 & 6.85 & 0.36 & 34 & 58 & 14 & 0.78 & 0.27 & 6.72 & 0.39 & 51 & 38 & 10 \\
\hline & $\mathrm{SE}$ & 1.05 & 0.38 & 9.34 & 0.44 & 47 & 67 & 25 & 0.94 & 0.45 & 7.09 & 0.43 & 46 & 46 & 71 \\
\hline \multicolumn{16}{|c|}{ LSD 0.05} \\
\hline \multirow{2}{*}{\multicolumn{2}{|c|}{$\begin{array}{l}\text { Section within time } \\
\text { Time within section }\end{array}$}} & 0.11 & 0.1 & 1.08 & 0.06 & 23 & 13 & 9 & 0.11 & 0.07 & 0.95 & 0.07 & 10 & 17 & 11 \\
\hline & & 0.12 & 0.09 & 1.19 & NS & NS & NS & NS & NS & 0.08 & 0.96 & NS & NS & NS & NS \\
\hline
\end{tabular}

${ }^{\overline{2}}$ Values mean of three cultivars and four Ca rates.

${ }^{y} \mathrm{BE}=$ blossom-end, $\mathrm{SE}=$ stem-end.

${ }^{x}$ Acetic acid extractable $\mathrm{Ca}$.

"Days from anthesis.

J. Amer. Soc. Hort. Sci. 118(2):201-206. 1993. 
but 'Tri-X Seedless' had significantly lower concentrations for both $\mathrm{Ca}$ fractions. This trend was reversed for $\mathrm{K}$ concentration, with 'Tri-X Seedless' containing more $\mathrm{K}$ than either of the other cultivars. These data support previous reports where $\mathrm{K}$ and $\mathrm{Ca}$ uptake were found to be inverse (Elmstrom et al., 1973). Concentrations of $\mathrm{Mg}, \mathrm{Zn}, \mathrm{Fe}$, and $\mathrm{Mn}$ also varied among cultivars, with 'Crimson Sweet' containing a higher concentration of $\mathrm{Mg}$, $\mathrm{Fe}$, and Mn than the other two cultivars.

In contrast to leaf tissue, rind elemental $\mathrm{Ca}$ concentration was not affected by $\mathrm{Ca}$ treatment. Total $\mathrm{Ca}$ concentrations in fully expanded leaf tissue ranged from $100 \%$ to $500 \%$ higher than those of fruit rind tissue (Tables 2 and 3). The $\mathrm{Ca}$ concentration in watermelon fruit rind tissue was highly variable in relation to $\mathrm{Ca}$ rate. However, there was a significant $\mathrm{Ca}$ rate and rind section interaction on the accumulation of total and acetic acid extractable $\mathrm{Ca}$ in rind tissue. Calcium concentrations in watermelon fruit harvested at Stillwater in 1989 and 1990 were curvilinearly related to increasing $\mathrm{Ca}$ rate. Total and extractable $\mathrm{Ca}$ concentrations in rind tissue from either the blossom or stem-end peaked in response to the the $560 \mathrm{~kg} \cdot \mathrm{ha}^{-1}$ treatment, with a distinctive drop at the 1120 $\mathrm{kg} \cdot \mathrm{ha}{ }^{-1} \mathrm{Ca}$ rate (Table 3 ).

The total $\mathrm{Ca}$ concentration in watermelon rind tissue harvested at Bixby increased during the development of the fruit (Tables 4 and 5). However, imported $\mathrm{Ca}$ was partitioned unequally within the melon, with the stem-end consistently maintaining a higher concentration of total $\mathrm{Ca}$ than the blossom-end. The acetic acid extractable $\mathrm{Ca}$ in the rind tissue was more variable than the total $\mathrm{Ca}$ fraction, however, at maturity, the stem-end had a significantly higher concentration of extractable $\mathrm{Ca}$ when compared to the blossom-end (Table 4).

At Stillwater in 1989, in contrast, the total Ca concentration in the blossom-end of the fruit continued to increase to maturity, while the levels of extractable $\mathrm{Ca}$ declined steadily during the ontogeny of the watermelon fruit. For both locations, K concentration increased over time in the stem-end of the fruit and increased in the blossom-end up to 21 days, then remained nearly unchanged through maturity (Table 4). Concentrations of $\mathrm{Mg}, \mathrm{Zn}, \mathrm{Fe}$, and $\mathrm{Mn}$ differed based on the section being sampled rather than the stage of fruit development.

During both years, genotypic characteristics had a significant

Table 5. Influence of sampling time and section on the elemental concentration of watermelon rind (1990). ${ }^{2}$

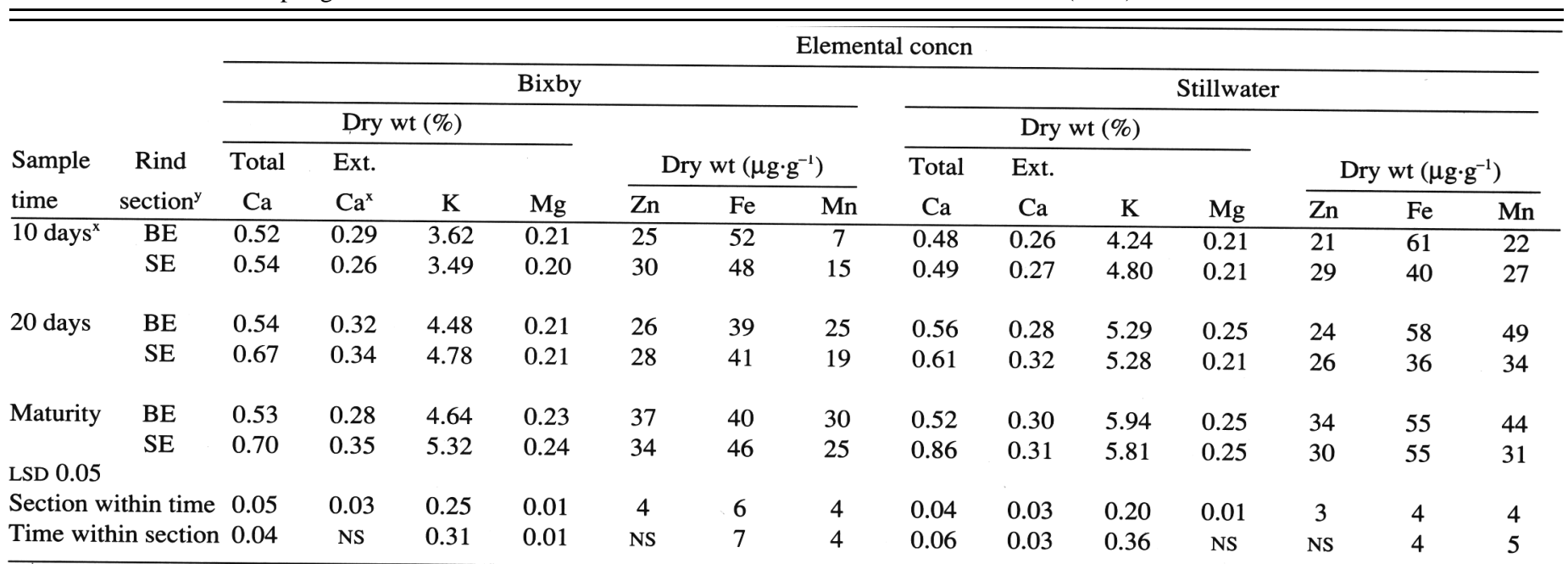

${ }^{2}$ Values mean of three cultivars and four Ca rates.

${ }^{\mathrm{B}} \mathrm{BE}=$ blossom-end, $\mathrm{SE}=$ stem-end.

'Acetic acid extractable Ca.

"Days from anthesis.

Table 6. Influence of cultivar on the elemental concentration of watermelon rind. ${ }^{2}$

\begin{tabular}{|c|c|c|c|c|c|c|c|c|c|c|c|c|c|c|}
\hline \multirow{5}{*}{ Cultivar } & \multicolumn{14}{|c|}{ Elemental concn } \\
\hline & \multicolumn{7}{|c|}{ Bixby } & \multicolumn{7}{|c|}{ Stillwater } \\
\hline & \multicolumn{4}{|c|}{ Dry wt $(\%)$} & & & & \multicolumn{4}{|c|}{ Dry wt $(\%)$} & & & \\
\hline & \multirow{2}{*}{$\begin{array}{c}\text { Total } \\
\mathrm{Ca}\end{array}$} & \multirow{2}{*}{$\begin{array}{l}\text { Ext. } \\
\mathrm{Ca}^{y}\end{array}$} & \multirow[b]{2}{*}{$\mathbf{K}$} & \multirow[b]{2}{*}{$\mathrm{Mg}$} & \multicolumn{3}{|c|}{ Dry wt $\left(\mu \mathrm{g} \cdot \mathrm{g}^{-1}\right)$} & \multirow{2}{*}{$\begin{array}{c}\text { Total } \\
\mathrm{Ca} \\
\end{array}$} & \multirow{2}{*}{$\begin{array}{c}\text { Ext. } \\
\mathrm{Ca}\end{array}$} & \multirow[b]{2}{*}{$\mathrm{K}$} & \multirow[b]{2}{*}{$\mathrm{Mg}$} & \multicolumn{3}{|c|}{ Dry wt $\left(\mu \mathrm{g} \cdot \mathrm{g}^{-1}\right)$} \\
\hline & & & & & $\mathrm{Zn}$ & $\mathrm{Fe}$ & $\mathrm{Mn}$ & & & & & $\mathrm{Zn}$ & $\mathrm{Fe}$ & $\mathrm{Mn}$ \\
\hline \multicolumn{15}{|c|}{1989} \\
\hline Charleston Gray & $0.95 \mathrm{a}$ & $0.40 \mathrm{a}$ & $6.84 \mathrm{c}$ & $0.43 \mathrm{a}$ & $60 a$ & $65 \mathrm{a}$ & $26 a$ & $0.91 \mathrm{a}$ & $0.44 \mathrm{a}$ & $5.81 \mathrm{a}$ & $0.43 \mathrm{a}$ & $51 \mathrm{a}$ & $57 \mathrm{a}$ & $26 a$ \\
\hline Crimson Sweet & $0.93 \mathrm{a}$ & $0.38 \mathrm{a}$ & $7.31 \mathrm{~b}$ & $0.41 \mathrm{a}$ & $63 \mathrm{a}$ & $63 \mathrm{a}$ & $22 \mathrm{a}$ & $0.83 \mathrm{a}$ & $0.39 \mathrm{a}$ & $6.24 \mathrm{a}$ & $0.41 \mathrm{a}$ & $50 \mathrm{a}$ & $57 \mathrm{a}$ & $22 a$ \\
\hline Tri-X Seedless & \multicolumn{14}{|c|}{1990} \\
\hline Charleston Gray & $0.62 \mathrm{a}$ & $0.32 \mathrm{a}$ & $4.23 \mathrm{~b}$ & $0.23 \mathrm{a}$ & $31 \mathrm{~b}$ & $45 \mathrm{a}$ & $22 \mathrm{a}$ & $0.61 \mathrm{a}$ & $0.33 \mathrm{a}$ & $4.96 \mathrm{c}$ & $0.25 \mathrm{a}$ & $30 \mathrm{a}$ & $54 \mathrm{a}$ & $37 \mathrm{a}$ \\
\hline Crimson Sweet & $0.61 \mathrm{a}$ & $0.31 \mathrm{a}$ & $4.89 \mathrm{a}$ & $0.21 \mathrm{a}$ & $36 \mathrm{a}$ & $44 \mathrm{a}$ & $21 \mathrm{a}$ & $0.58 \mathrm{a}$ & $0.30 \mathrm{a}$ & $5.49 \mathrm{a}$ & $0.23 \mathrm{a}$ & $31 \mathrm{a}$ & $51 \mathrm{a}$ & $36 \mathrm{a}$ \\
\hline Tri-X & $0.49 \mathrm{~b}$ & $0.24 \mathrm{~b}$ & $4.67 \mathrm{a}$ & $0.20 \mathrm{a}$ & $29 \mathrm{~b}$ & $41 \mathrm{a}$ & $20 a$ & $0.52 \mathrm{~b}$ & $0.26 \mathrm{~b}$ & $5.20 \mathrm{~b}$ & $0.22 \mathrm{a}$ & $23 \mathrm{~b}$ & $46 b$ & $33 \mathrm{a}$ \\
\hline
\end{tabular}

$\overline{{ }^{2}}$ Means of four Ca rates and two sections. Mean separation within column and location by Duncan's multiple range test, $P=0.05$.

${ }^{y}$ Acetic acid extractable Ca. 
Table 7. Incidence of BER in 'Charleston Gray' melons as affected by $\mathrm{Ca}$ applied to soil (gypsum).

\begin{tabular}{lccccc}
\hline \hline & \multicolumn{4}{c}{ No. of BER affected fruits } \\
\cline { 2 - 6 } Ca applied & \multicolumn{3}{c}{1989} & & \multicolumn{3}{c}{1990} \\
\cline { 2 - 5 }$\left(\mathbf{k g} \cdot \mathrm{ha}^{-1}\right)$ & Bixby & Stillwater & Bixby & Stillwater \\
\hline 0 & $9^{z}$ & 8 & 13 & 12 \\
280 & 6 & 11 & 11 & 11 \\
560 & 5 & 4 & 7 & 4 \\
1120 & 2 & 2 & 4 & 3 \\
Linear & $*$ & NS & $*$ & $*$ \\
Quadratic & NS & $*$ & NS & NS \\
& & & &
\end{tabular}

${ }^{\sqrt{5}}$, Nonsignificant or significant at $P=0.05$.

impact on the elemental concentration in watermelon rind tissue (Table 6). For both years and locations 'Tri-X Seedless' had total $\mathrm{Ca}$ concentrations lower than 'Charleston Gray' or 'Crimson sweet'. This was also true for the extractable $\mathrm{Ca}$ fraction. 'Tri-X Seedless' rind tissue also had a lower percentage of the total $\mathrm{Ca}$ in the acetic acid extractable fraction than the other two cultivars. In the 1989 growing season, $37 \%$ of the total $\mathrm{Ca}$ fraction in 'Tri-X Seedless' was extractable Ca. For 'Charleston Gray' and 'Crimson Sweet', the extractable Ca fraction constituted $45 \%$ of the total Ca. Concentrations for most elements were higher in 1989 than they were in 1990 (Table 6).

Tissue $\mathrm{K}$ concentration differed among the three cultivars, except at Stillwater in 1989. 'Tri-X Seedless' and 'Crimson Sweet' had higher K concentrations than 'Charleston Gray' (Table 6). Magnesium, $\mathrm{Zn}, \mathrm{Fe}$, and $\mathrm{Mn}$ concentrations were usually not significantly different among cultivars.

Mean red flesh Hunter 'a' color values ranged from 19.8 to 24.9 and were not significantly affected by $\mathrm{Ca}$ fertilization or cultivar. Fruit heart tissue SSC ranged from $9.1 \%$ to $11.1 \%$ and were independent of treatment.

BER is a physiological disorder of watermelon commonly attributed to inadequate $\mathrm{Ca}$ concentrations in the affected tissue (Foroughi and Kloke, 1974, Walters and Nettles, 1961). Increasing rates of soil-incorporated $\mathrm{Ca}$ reduced the incidence of BER in 'Charleston Gray' watermelons (Table 7). Only five 'Crimson Sweet' fruit were affected with BER in each of the two years. The 'Tri-X Seedless' watermelon was completely resistant to the disorder.

Discussion

The positive relation between elemental concentrations for total and extractable $\mathrm{Ca}$ of leaves and soil-incorporated $\mathrm{Ca}$ rates (Fig. 1) indicates that gypsum is an adequate source of $\mathrm{Ca}$ for field mineral nutrition of watermelon, at least in cases where the $\mathrm{pH}$ adjusting benefit of lime is not required. Root systems of melon plants grown with plastic mulch tend to be confined near the surface and within the polyethylene mulch bed (Bhella, 1985).

Recognizable foliar symptoms of $\mathrm{Ca}$ deficiency are seldom observed in field-grown fruit or vegetable crops. Calcium becomes limiting due to an inefficient distribution of $\mathrm{Ca}$ by the transpirative stream to growing tissue rather than low Ca uptake (Kirkby and Pilbeam, 1984). As a result of different $\mathrm{Ca}$ allocation and remobilization, Ca concentrations in watermelon leaves and fruits were not directly related. These results agree with conclusions drawn from studies conducted on Ca nutrition of cucumber (Cucumis sutivus L.) (Engelkes et al., 1990).

Elemental concentrations in the stem-end of rind tissue increased during fruit development (Tables 4 and 5). These data indicate that imported $\mathrm{Ca}$ is first deposited at the stem-end and that transport to the blossom-end may be impeded, at least late in development. This gradient in $\mathrm{Ca}$ concentration from the stem to blossom-end also has been observed in cucumber and hypothesized as $\mathrm{Ca}$ depletion from the xylem solution during the transport (Frost and Kretchman, 1989). Tissue from the blossom-end consistently had a lower total $\mathrm{Ca}$ concentration $(0.68 \%$ to $0.87 \%, 1989 ; 0.48 \%$ to $0.56 \%, 1990)$ than tissue in the stem-end $(0.88 \%$ to $1.05 \%, 1989$; $0.49 \%$ to $0.86 \%, 1990)$.

Transport of $\mathrm{Ca}$ into the stem-end of watermelon fruit continues to maturity, while accumulation in the blossom-end slows significantly 7 to 10 days before harvest (Tables 4 and 5). This trend may be due to reduced movement of $\mathrm{Ca}$ into the blossom-end and/ or dilution of the existing concentrations of the elements as the fruit grew. Whatever the cause, all three cultivars studied exhibited the same trend.

Cultivar differences were evident for the accumulation of $\mathrm{Ca}$ in watermelon rind tissue (Table 6). Differences in resistance of tomato cultivars to BER have been shown to bedue to differences in efficiency of $\mathrm{Ca}$ uptake and accumulation in the fruit or to differences in the $\mathrm{Ca}$ concentration in the fruit (Greenleaf and Adams, 1969).

This study did not elucidate the basis for the variation among cultivars in regard to Ca nutrition. However, 'Tri-X Seedless' fruit consistently had lower concentrations of total and extractable $\mathrm{Ca}$ in leaf and rind tissue than the other two test cultivars. Despite maintaining a lower $\mathrm{Ca}$ concentration, 'Tri-X Seedless' demonstrated a complete resistance to BER. However, 'Charleston Gray' with a relatively high concentration of total $\mathrm{Ca}$ in the rind had a high incidence of BER. Further investigation is needed to adequately describe the histological and physiological differences among these cultivars. These findings are in agreement with work conducted previously (Sundstrom and Carter, 1983).

Cultivar selection and environmental influences all combine to influence the elemental status of plant tissues. This study clearly shows that the cultivar chosen is nearly as important as external pressures applied by the environment, at least relative to soil $\mathrm{Ca}$ levels ( $\mathrm{pH}$ not being limiting).

Elemental concentrations in the leaf and rind tissue were significantly influenced by the environment within each year. Accumulation of nearly all elements was higher during the 1989 than the 1990 growing season (Table 6). In 1989 the watermelons were infected by a severe outbreak of the foliar disease anthracnose [Colletotrichum orbiculare (Berk. \& Mont.) Arx]. The disease reduced biomass production, which in turn may have concentrated the elements resulting in increased elemental concentrations. Precipitation was significantly higher in 1989 than in 1990. Although 
all plots were maintained at adequate soil moisture levels and monitored using tensiometers, in 1989 the soil profile adjacent to the plots was wetter, and this condition may have led to increased uptake of nutrients.

\section{Literature Cited}

Bangerth, F. 1976. A role of auxin and auxin transport inhibitors on the $\mathrm{Ca}$ content of artificially induced parthenocarpic fruits. Physiol. Plant. 37:191-194.

Bangerth, F. 1979. Calcium-related physiological disorders of plants. Annu. Rev. Phytopathol 17:97-122.

Bhella, H.S. 1985. Muskmelon growth, yield, and nutrition as influenced by planting method and trickle irrigation. J. Amer. Soc. Hort. Sci. 110:793-796.

Bradley, G.A. and J.W. Fleming. 1959. Fertilization and foliar analysis studies on watermelons. Arkansas Agr. Expt. Sta. Bul. 610.

Cirulli, M. 1974. Primi risultati sulla resistenza varietal e sull' influenza della frequenza irrigua nel "marciume apicale" del' anguria. Phytopathol. Mediterranean 13:82-86.

Cirulli, M. and F. Ciccarese. 1981. Effect of mineral fertilizers on the incidence of blossom-end rot of watermelon. Phytopathology 7 1:50-53.

Elmstrom, G.W., J.G.A. Fiskell, and F.G. Martin. 1973. Watermelon yield and quality: Effect of fertilizer rate and placement. Proc. Fla. State Hort. Soc. 86:196-200.

Engelkes, L.A., I. Widders, and H. Price. 1990. Ontogenetic changes in calcium concentration and content in pickling cucumber fruit as influenced by genotype and environment. J. Amer. Soc. Hort Sci. 115:555-558.

Foroughi, M. and A. Kloke. 1974. Blütenend Faüle an Citrullus vulgaris
Wassermelone. Plant \& Soil. 40:57-64.

Francis, F.J. 1980. Color quality evaluation of horticultural crops. HortScience 15:58-59.

Frost, D.J. and D.W. Kretchman. 1989. Calcium deficiency reduces cucumber fruit and seed quality. J. Amer. Soc. Hort. Sci. 114:552-556.

Gallaher, R.N. and J.B. Jones. 1976. Total, extractable, and oxalate calcium and other elements in normal and mouse ear pecan tree tissue. J. Amer. Soc. Hort. Sci. 101:692-696.

Greenleaf, W.H., and F. Adams. 1969. Genetic control of blossom-end rot disease in tomatoes through calcium metabolism. J. Amer. Soc. Hort. Sci. 94:248-250.

Isaac, R.A. and W.C. Johnson, Jr. 1975. Collaborative study of wet and dry techniques for the elemental analysis of plant tissue by atomic absorption spectrophotometery. Assn. Offic. Anal. Chemists. 58:436.

Jones, J.R., S.S. Waltz, and P.H. Everett. 1975. Effect of liming and nitrogen source on fusarium wilt of cucumber and watermelon. Proc. Fla. State Hort. Soc. 88:200-203.

Kirkby, E.A. and D.J. Pilbeam. 1984. Calcium as a plant nutrient. Plant Cell \& Environ. 7:397-405.

Lacascio, S.J. and H.W. Lundy. 1962. Lime and minor element studies on watermelon. Proc. Fla. State Hort. Soc. 75:131-136.

Shear, C.B. 1975. Calcium-related disorders of fruits and three vegetables. HortScience 10:361-365.

Sundstrom, F.J. and S.J. Carter. 1983. Influence of K and Ca on quality and yield of watermelon. J. Amer. Soc. Hort. Sci. 108:879-881.

Walters, W.E. and V.F. Nettles. 1961. The influence of hydrated lime and nitrogen on the yield, quality and chemical composition of the Charleston Gray watermelon. Proc. Amer. Soc. Hort. Sci. 77:503-507.

Wiersum, L.K. 1979. Effects of environment and cultural practices on calcium nutrition. Commun. Soil Sci. Plant Anal. 10:259-278. 